Discussion Paper No. 06-046

Market Discipline and the Use of Government Bonds as Collateral in the EMU

Katrin Ullrich

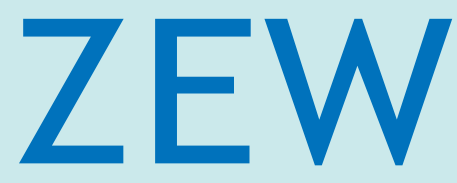

Zentrum für Europäische Wirtschaftsforschung $\mathrm{GmbH}$

Centre for European Economic Research 
Discussion Paper No. 06-046

\title{
Market Discipline and the Use of Government Bonds as Collateral in the EMU
}

\author{
Katrin Ullrich
}

Download this ZEW Discussion Paper from our ftp server:

ftp://ftp.zew.de/pub/zew-docs/dp/dp06046.pdf

Die Discussion Papers dienen einer möglichst schnellen Verbreitung von neueren Forschungsarbeiten des ZEW. Die Beiträge liegen in alleiniger Verantwortung der Autoren und stellen nicht notwendigerweise die Meinung des ZEW dar.

Discussion Papers are intended to make results of ZEW research promptly available to other economists in order to encourage discussion and suggestions for revisions. The authors are solely responsible for the contents which do not necessarily represent the opinion of the ZEW. 


\section{Non-technical Summary}

The confidence that financial markets can substantially restrict the debt behaviour of governments is not high. One reason for the lack of market discipline could be that the European Central Bank (ECB) accepts all government bonds of the EU governments at the same conditions as eligible for monetary policy transactions. A differentiation with respect to potentially varying risk levels is not given. This could support the idea that government bond in the EU are equally secure and have the same low default risk.

The use of government bonds as collateral in monetary policy transactions with the ECB has declined since 1999. Even if the ECB has not yet excluded securities from the list of eligible assets, this list contains an explicit enumeration of eligible assets. All bonds issued from governments of the EU are contained in the class with the lowest risk, despite large differences in debt and deficit. The acceptance of all government bonds at the same conditions is not followed by the markets, as the ratings of private rating agencies show.

The rating of the central bank and the rating of the private agencies can be seen as two signals about the default risk of government bonds. Because the central bank and the rating agencies are expected to devote a considerable amount of resources to the assessment of the default risk of government bonds, we assume that the institutions identify the risk correctly on average. However, the assessed risk will not be correct in any case. The extent to which rating signals affect investors' expectations about the default risk of government bonds will then depend on the relationship between the evaluation error of the institutions. An effect of the ECB classification of a government bond on the risk premium can only arise theoretically if the error of the ECB is independent from that of the rating agency. In case of unbiased signals of the ECB and the agency, and the ECB signal depending on that of the rating agency, investors would ignore the signal of the ECB.

If financial markets see the ECB as an independent source of information with regard to the default risk of government bonds, the classification as eligible assets for monetary policy transactions could influence the risk premia of bonds. In this case, it could be that the registration as eligible assets of all government bonds of the EU leads to more uniform risk premia than without this signal. 


\title{
Market Discipline and the Use of Government Bonds as Collateral in the EMU
}

\author{
Katrin Ullrich*
}

June 2006

\begin{abstract}
The confidence that financial markets are able to discipline the debt behaviour of governments is not very high. Therefore, the Stability and Growth Pact has been implemented as an institutional constraint to substitute for the market mechanism. With the weakening of the Pact, market discipline could gain importance again. To strengthen market discipline, reasons for its failure in the euro area have to be analysed. One possible reason could be that the European Central Bank accepts all European government bonds without distinction in its monetary policy auctions as collateral. This could provide the financial market with a signal that these government securities are equally (non-)risky and that a differentiation with respect to risk premia is not needed.
\end{abstract}

JEL Classification: E51, E52, G12, H63

Key Words: Stability and Growth Pact, Market Discipline, Collateral, Repo

${ }^{*}$ Centre for European Economic Research, Mannheim, P.O. Box 1034 43, D-68034 Mannheim, Germany; ullrich@zew.de. The author is currently also a scholar at the 'WIN-Kolleg' of the Heidelberg Academy of Sciences. The financial support of the Heidelberg Academy of Sciences ('Heidelberger Akademie der Wissenschaften') for the project 'Legitimacy of a European Constitution' is gratefully acknowledged. I thank Matthias Köhler, Sandra Schmidt, and Michael Schröder for helpful comments and suggestions. 


\section{Introduction}

The Stability and Growth Pact (SGP) has attracted much attention in academic literature as well as in political debate. With the escape of Germany and France from punishment by the rules of the SGP in 2002/03, the Pact seems to be irretrievably damaged. This process of dissolving fiscal restriction is reinforced by the adaptation of the rules to countryspecific developments. Other means, apart from restrictions exerted from the European level on the debt behaviour of governments, could be market mechanisms imposing market discipline on new issues of government bonds. In the following, we analyse whether the classification of governments bonds as eligible assets in the monetary policy transactions of the European Central Bank (ECB) could have an influence on market discipline.

Up to now, the SGP has replaced market discipline. One rationale of the Pact is the protection of the monetary policy of the ECB, see e.g. Artis and Winkler (1997), Beetsma and Uhlig (1999), or Eichengreen and Wyplosz (1998). Excessive deficits and hence unsustainable debt of the member states of the monetary union could have detrimental effects on interest and inflation rates and would, therefore, endanger the objective of price stability pursued by the ECB. The ECB is then forced to react to economic effects of fiscal policy. To guarantee the independence of monetary policy and the priority of monetary before fiscal policy at the European level, the SGP was implemented. There are other reasons, but the support of price stability by the Pact has been stressed by the ECB itself repeatedly (e.g. ECB Press release, 24 October 2002 - Statement of the Governing Council on the Stability and Growth Pact; ECB Monthly Bulletin, January 2005).

With the weakening of the Pact, the role of financial markets in evaluating the sustainability of fiscal policy in the member states of the euro area becomes more important. The institutional commitment by the member states is only necessary if financial markets do not prevent the issue of new debt, by demanding high interest rates if the issuing government is highly indebted. If the risk premium would be rather high, it would reduce the issue of new debt because debt service would be more expensive. But there are several reasons why financial markets might not punish high government debt in the euro area.

One reason could be that the institutional aspects of the euro system itself prevent the formation of spreads between government bond yields, because the ECB permits government securities to be used as collateral in monetary policy operations without distinction between high and low debt countries. This could generate opposing influences on the pricing of securities. On the one hand, prices of securities should be the same because 
they are used to get liquidity at the same interest rate set by the ECB. On the other hand, financial markets should charge different risk premia for government bonds with the same maturity, depending on the issuing government.

One characteristic of the Eurosystem is the charging of a uniform interest rate in the Main Refinancing Operations (MRO) of monetary policy where transactions are based on different kinds of collateral. The following analysis investigates the influence of this institutional feature on the development of interest rate spreads of government bonds because of different risk premia. Because there are no changes in the classification of government bonds as eligible assets, which could be employed in an empirical investigation, we rely on a theoretical model to capture the potential influence of this classification on the risk premium of government bonds. We come to the conclusion that the classification of government bonds, as eligible in monetary policy transaction only, has an influence on the risk premium if the central bank is perceived as an independent source of information with regard to the default risk of the bond. If the assessment of the central bank is somehow correlated with the assessments of private rating agencies, the relative influence depends on the expected precision of the information.

To investigate the possible influence of classification of bonds as collateral by the central bank on the price of a security, we proceed as follows. In the first section, we review shortly the necessity of the SGP because of failing market discipline. With a weakening of the Pact, market discipline may gain importance. Therefore, we summarise the rationale of the Pact with regard to protection of common monetary policy by restricting fiscal policy of the member states and the failure of market discipline in the EMU. To get an idea of the importance of governments bonds, we take a look at the share of governments on securities as a whole and the share of government securities in collateral use, in the third section. For effective governance of financial markets on governments, there should be no constraints that hinder the market mechanism. We describe the open market operations of the Eurosystem in detail, stressing the institutional feature of a single interest rate for different kinds of collateral, especially securities issued by different governments, in the forth section. Because the central bank gives, with the classification as eligible asset, a rating with regard to the risk of government bonds, we also take a look at a related risk assessment, the rating provided by rating agencies. In the fifth section, we develop a small theoretical model of the influence of central bank and rating agencies on the expected risk premium of a bond. The set up of the model relies on the results of the analysis so far. The sixth section concludes the analysis. 


\section{Market Discipline or Stability and Growth Pact?}

The SGP tries to prevent unsustainable borrowing of governments in the EMU. The procedure starts if a member state violates the three percent threshold for the deficit as a fraction of GDP. The institutionalised rules of the SGP replace market discipline in restraining debt behaviour of governments. It could be questioned, whether the Pact is necessary (e.g. Bofinger 2003, or Hefeker 2003), and whether the rules serve their purposes (Eijffinger 2003). The SGP has strategic advantages and economic disadvantages due to its inflexibility as argued by Heinemann (2004). Because of its serious weaknesses, it is not surprising that there are numerous proposals to reform the Pact, e.g. Boonstra (2005), Eijffinger (2005), or Casella (1999).

Independent of other purposes of the SGP, the rules should, first and foremost, discipline the deficit spending of governments in the EMU. An alternative to this institutional setup is a market-based solution: financial markets would sanction unsustainable fiscal policy by imposing a higher risk premium on government bonds issued by highly indebted governments. If the debt of a country is not sustainable any longer and the default risk rises enough, the risk premium for government bonds should increase. This would make the issue of new debt more costly and would possibly make debt service of circulating bonds more expensive for the government. The higher costs of new debt would reduce the incentive to issue new securities. In this ideal scenario (Lane 1993), a market mechanism would punish a too high a government debt, even if market discipline is exposed to special problems in case of sovereigns (Scott 2004). Such a mechanism would support the opinion that the market is better at information gathering and aggregating than governments. With the SGP, the governments decide based on a simple and fixed number whether the debt level of a country is unsustainable. The market-based solution is of particular interest if disciplining should not take effect even with a Pact that has been changed to take the economic situation of the countries into account (European Commission 2004).

The more effective the market mechanism, the easier additional institutional restrictions on deficit and debt can be renounced. The literature provides evidence in favour of country-specific risk premia in Europe, which are higher, the higher the debt level is, e.g. Codogno et al. (2003) or Lemmen and Goodhart (1999). The influence of higher than average debt on long-term interest rates is estimated to be about 10 basis points for a one percentage point increase of primary deficit to GDP for OECD countries (Ardagna, Caselli, and Lane 2004). There seems to be at least the potential for a disciplining effect 
of financial markets on fiscal policy, even if an increase of the long term real rate by 3 basis points in reaction to a rise of one percent debt in relation to GDP seems more realistic as argued by Engen and Hubbard (2004), at least in the US.

For Europe, the picture changed most probably with the starting of the EMU and the economic convergence before 1999 to achieve an economy for which a common monetary policy would be possible. Because of the monetary union, risk premia fell, but this advantage decreases with the level of debt (Bernoth, Schuhknecht, and von Hagen 2004). The overall results regarding market discipline hint to a threshold effect. However, another interpretation of the lacking discipline would be that financial markets are not able or willing to discriminate between countries and do not charge debt-dependent risk premia. The cost of new debt would be too low for a government to prevent unsustainable policies. Even in the time of the gold standard, market discipline was not enough to provide a sufficient incentive for governments to restrain from borrowing too much (Flandreau and Zumer 1998).

A comparison of the 10 year bond yields of the euro area countries shows that the time series fell to an almost similar level since the beginning of the nineties. Figure 1 shows the difference in yields of the respective countries compared to German bonds. There seem to be three groups of countries and Greece. The Greek bond yield is a special case that shows the biggest difference to the German yield, temporarily about 18 percentage points. Nevertheless, the spread declined considerably to a level of about 0.2 percentage points in November 2005. The other euro area countries can be classified into three groups according to the initial level of the spread. The first group consists of France, the Netherlands, and Austria with a spread that has been relatively low since 1992. For the observed time period, the mean of the spread is less than 0.2 percentage points for each of the countries. Belgium and Ireland form the second group. They started with a higher spread. However, since 1998 the difference between the yields has been comparable to that of the first group. The third group contains Spain, Italy, Portugal and Finland with an initial spread of about 4.5 to 6.5 percentage points. Again, since 1998 the spread is comparable to that of the other two groups. There seems to be no remarkable difference between government bond yields despite the different debt levels in the euro area. Overall, the fear has been expressed that "access to financing will be easier in the unified European capital market and (presumably) cheaper for high debt and deficit countries, no longer suffering national interest rate premia for devaluation and inflation risk. Abolishing national currencies removes the disciplining effect of international currency markets on national fiscal policies 

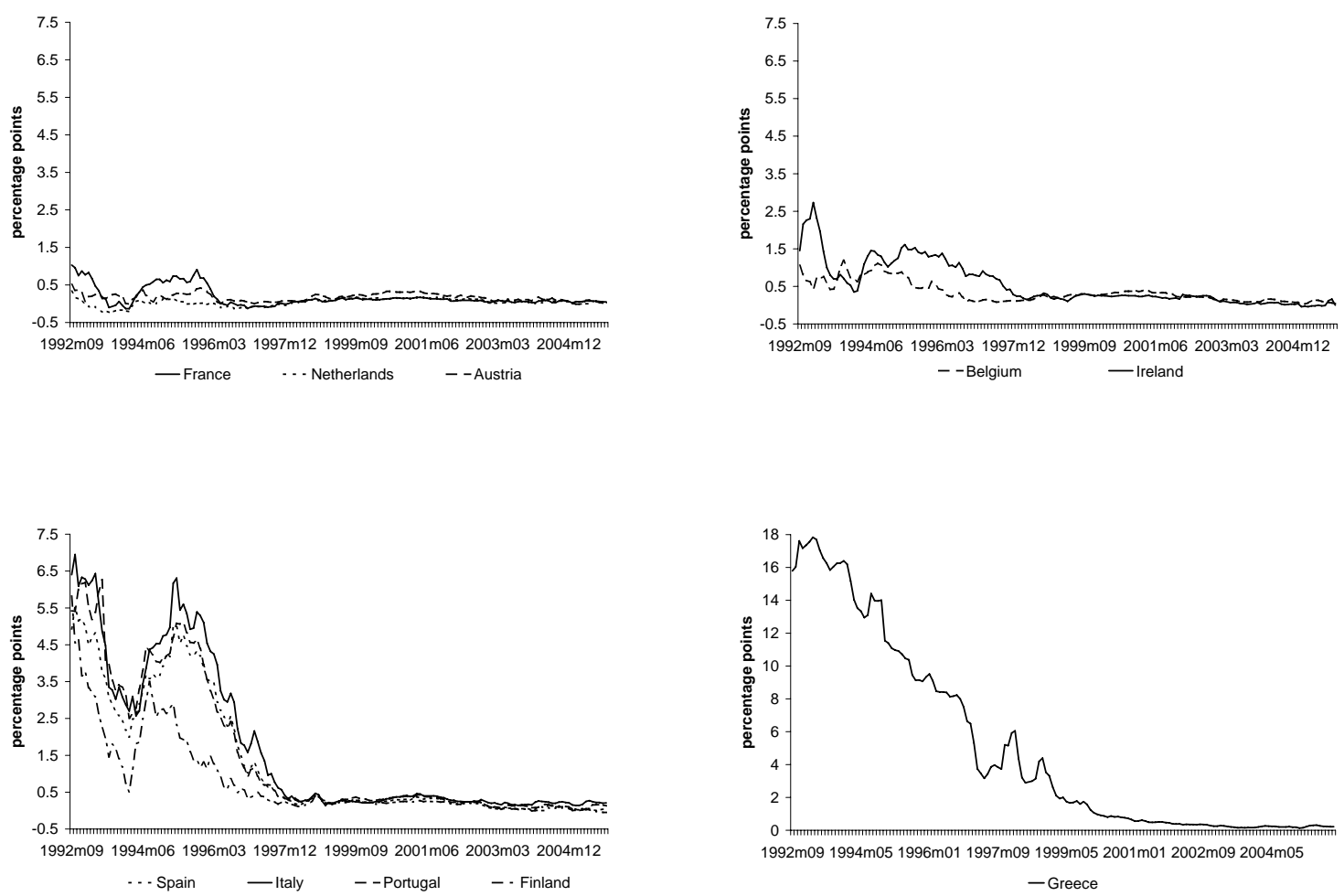

Figure 1: Spread of 10 year bond yield to German 10 year bond yield (Source: Eurostat).

$[\ldots]$, even though bond markets may be expected to correctly price the remaining default risk" (Artis and Winkler 1997). As long as states have sufficient tax powers, the default premia will not be large enough to prevent unsustainable fiscal policy.

The lacking ability of financial markets to sufficiently prevent deficit-spending in high-debt countries in the EMU is attributed to different reasons (see an overview of arguments in de la Dehesa 2005, Fitoussi 2005 and Wyplosz 2005). The first is that the former Pact was so convincing that there was no need for financial markets to intervene and charge higher risk premia. The reform makes the SGP presumably more flexible, but also more vulnerable to political influence. If this assumption is correct, the developments to make the rules of the Pact more dependent on country-specific circumstances should have triggered a negative reaction by financial markets. This reaction did not show up, thereby contradicting the former assumption. The second reasoning relies on the assumption that financial markets work efficiently and that there is no default risk. Public debt would simply be too low to generate higher risk premia. Another assumption is that markets will act too late and then too much. If government debt rises, there is a critical threshold. If this threshold is 
passed, a reaction of financial markets is triggered but may be exaggerated and be similar to panicking behaviour. The overall reaction of financial markets to a growing government debt is presumably non-linear.

For market discipline to take effect, at least three assumptions must be fulfilled (e.g. Lane 1993, or Frenkel and Goldstein 1991). First, no restrictions prevent the reaction of financial markets to the debt level in a country and the bond market has to be highly developed. Second, investors need the respective information about the debt level. This alludes to the implicit government debt from social security systems, as well as off balance sheet transactions. Of course, investors cannot react to information not known to financial markets. Third, the possibility of a bail out has to be eliminated. If there is such a possibility, investor claims would be served and there is no risk that money is lost. The default risk is then nonexistent from the point of view of an investor.

The first two assumptions are most likely fulfilled in the EMU, but the last one deserves more attention. There is a no bail out clause in the EU Treaty (Article 103 (1)) that other states and institutions in the $\mathrm{EU}$ are forbidden to take on the obligations of an EU country that is insolvent. But the credibility of such a clause is not beyond doubt because of the ever-closer interdependence between the countries. Insolvency of a country, especially a larger one, would most likely have detrimental effects on other countries too. These effects would be more severe, the closer the links between the economies. Meeting the liabilities, especially if shared by a group of countries, could generate lower costs than let the country go bankrupt. Moreover, the credibility of agreements on the European level is not that high as the breached SGP has taught the markets already. This could support doubts with regard to the no bail out clause. For one thing, the ECB could bail out a country because the inflation costs of this salvation would be shared in the EMU (e.g. von Hagen 2003). ${ }^{1}$

Against this background, it seems questionable that financial markets could exercise a sufficiently effective and foresighted discipline on government indebtedness. They could, however, at least take on a complementary function to the institutional rules of the SGP (see e.g. Hedbávný et al. 2005). ${ }^{2}$ Nevertheless, even a simply supporting role of financial

\footnotetext{
${ }^{1}$ See Eichengreen and von Hagen (1996) for a discussion of the relationship between the no bail out clause and the Pact.

${ }^{2}$ Moreover, there is the opinion that market discipline is not even necessary in EMU because debt of a single member state is too small to affect the common interest rate. In this case, a default would have no external effects and the costs are borne by the respective country and its creditors alone (Buiter, Corsetti, and Roubini 1993). The precondition for this scenario is that the ECB is committed to price stability
} 
markets would assume that financial markets are able to charge the 'right' risk premia. But as Wyplosz (2005) puts the question, there may be institutional features of the Eurosystem that prevent the well-functioning of financial markets in this respect. Even if financial markets are highly developed as in the EU, there could be institutional features that prevent the proper working of these markets. One such feature could be the use of government securities as collateral in open market operations of the ECB. As the following analysis shows, this could send a signal about the quality of the debt similar to ratings of private agencies. That leads to a lower risk premium than it would be without this evaluation by monetary policy-makers.

To investigate the question of the possibilities of market discipline in the EMU in more detail, we proceed as follows. First, we give some numbers on government securities in the EMU to get a grasp of the importance of government bonds with respect to the securities market and open market operations. Second, we take a look at open market operations of the ECB.

\section{Government Securities in the EMU}

The basic condition for market discipline is that governments must be active in financial markets so that the market can evaluate government securities. With the EMU, central banks are prohibited to finance public spending directly. Therefore, the significance of government financing via financial markets should increase. This development could be influenced by a decreasing need for financing because of institutional restrictions for deficit and debt by the SGP.

Despite the Pact, the outstanding amount of government securities other than shares in the EMU has increased since 1999 (see Table 1). About 30 percent of these securities are owned by monetary financial institutions (MFI) without the Eurosystem. National central banks and the ECB own only a minor part of government securities compared to the other MFI, about 2.5 to 3 percent. The relative share of securities owned by the MFI's has virtually not changed since 1999. The same is true for the share of the Eurosystem. Compared to the total amount of securities, government securities represent an important share of this market. About 50 percent of all securities are government

and a bail out does not take place. Moreover, market participants had to be sure that the default of one country would have no detrimental effects on other European countries. That means that no spillover effects would take place. 


\begin{tabular}{|c|c|c|c|c|}
\hline \multirow{2}{*}{} & \multicolumn{2}{|c|}{$\begin{array}{c}\text { Government securities } \\
\text { in possession of }\end{array}$} & $\begin{array}{c}\text { Government securities } \\
\text { Gross issues } \\
\text { transactions }\end{array}$ & Outstanding amounts \\
\hline & MFIs without Eurosystem & Eurosystem & \\
\hline 1999 & 1123.8 & 86.1 & 1149.2 & 3451 \\
2000 & 995.9 & 93.6 & 1028.8 & 3547 \\
2001 & 1122.9 & 101.8 & 1135.5 & 3766 \\
2002 & 1170.4 & 86.0 & 1369.6 & 3941 \\
2003 & 1242.6 & 121.5 & 1566.3 & 4142 \\
2004 & 1299.9 & 140.0 & 1546.4 & 4370 \\
\hline
\end{tabular}

Table 1: Government securities other than shares, issues and outstanding amounts (Source: ECB Monthly Bulletin; ECB securities issues statistics).

\begin{tabular}{|c|c|c|c|}
\hline & $\begin{array}{c}\text { Share of government securities } \\
\text { to total amount of securities } \\
\text { (outstanding amounts) }\end{array}$ & $\begin{array}{c}\text { Share of government securities } \\
\text { to total assets in possession of } \\
\text { MFIs without Eurosystem }\end{array}$ & Eurosystem \\
\hline 1999 & 0.52 & 0.07 & 0.08 \\
2000 & 0.50 & 0.06 & 0.09 \\
2001 & 0.48 & 0.06 & 0.10 \\
2002 & 0.48 & 0.06 & 0.08 \\
2003 & 0.47 & 0.06 & 0.11 \\
2004 & 0.46 & 0.06 & 0.12 \\
\hline
\end{tabular}

Table 2: Shares of government securities to total assets (Source: ECB Monthly Bulletin; ECB securities issues statistics, own calculations).

securities. This share decreases since 1999 (see Table 2). In the aggregated balance sheet of MFIs, the importance of government securities is rather minor, around 6 percent and constant for MFIs without the Eurosystem. These numbers are slightly higher for the national central banks and the ECB. An increasing public financing through central banks by using securities is not visible. The substitution of direct credit of central banks by financing via the detour of financial markets seems not to take place.

The potentially increasing importance of government securities issues for public finances because of government financing via the financial markets is reflected in an increasing share of government securities to gross debt for the EMU as a whole. As Figure 2 shows, this 
development is based on the growth of securities to finance debt in European countries, which also experience a growing total debt. These countries are Germany, Greece, France, the Netherlands, and Austria. In Spain, Italy, and Portugal, the share of securities to debt is fairly constant. The share is relatively high for all countries except for Luxembourg, where it is rapidly declining. Germany started with the lowest share with around 60 percent in 1999 besides Luxembourg. The German share of government securities to debt has risen to nearly 70 percent in 2004 which is nevertheless still the lowest share of the EMU countries.

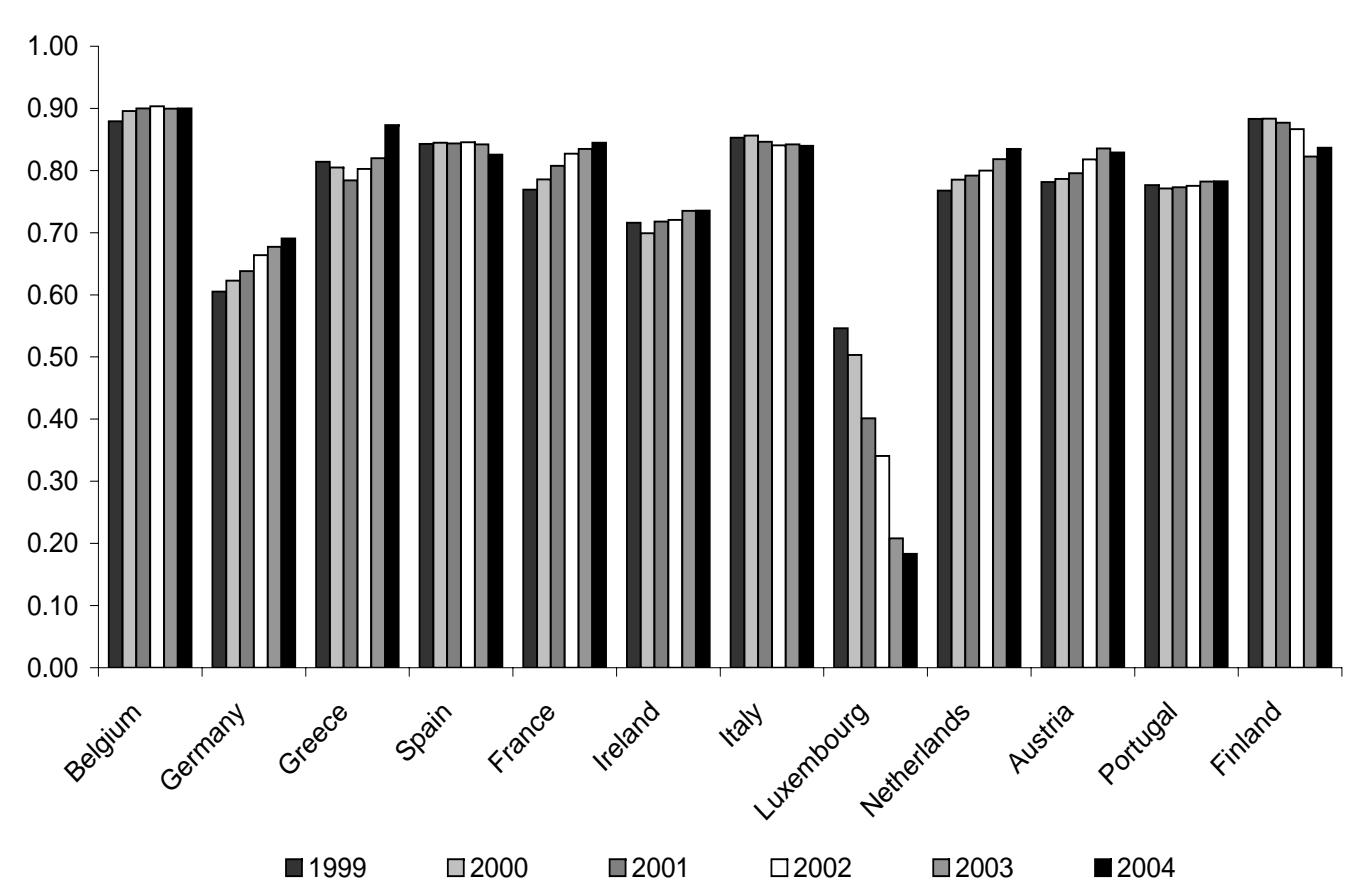

Figure 2: Government securities to gross debt (Source: Eurostat).

Government securities play an important role as collateral in monetary policy transactions between private and central banks. The average amount of securities used in credit transaction with the central bank was about 12 percent of the amount of eligible assets in 1999 and declined to about 10 percent in 2004 (see Figure 3). This discrepancy between eligible assets and securities, actually used as collateral, is even more pronounced for government securities than for securities as a whole. Here, the share declined from 9.8 to 7.3 percent. 
Another characteristic can also be extracted from Figure 3. The share of eligible assets as a whole to the outstanding amounts of securities declined slightly from 83.5 to 81.7 percent. About 20 percent of securities cannot be used in transactions with the central bank. For government securities, this share is considerably smaller. In 1999, 98.5 percent of the outstanding amount of governments securities were classified as eligible from the ECB. In 2004, the share was smaller with 96.5 percent, but still, nearly all of the government securities issued from member states in the euro area can be used in monetary policy transactions. The actual use of securities or government bonds as collateral is only a fraction of the eligible assets.

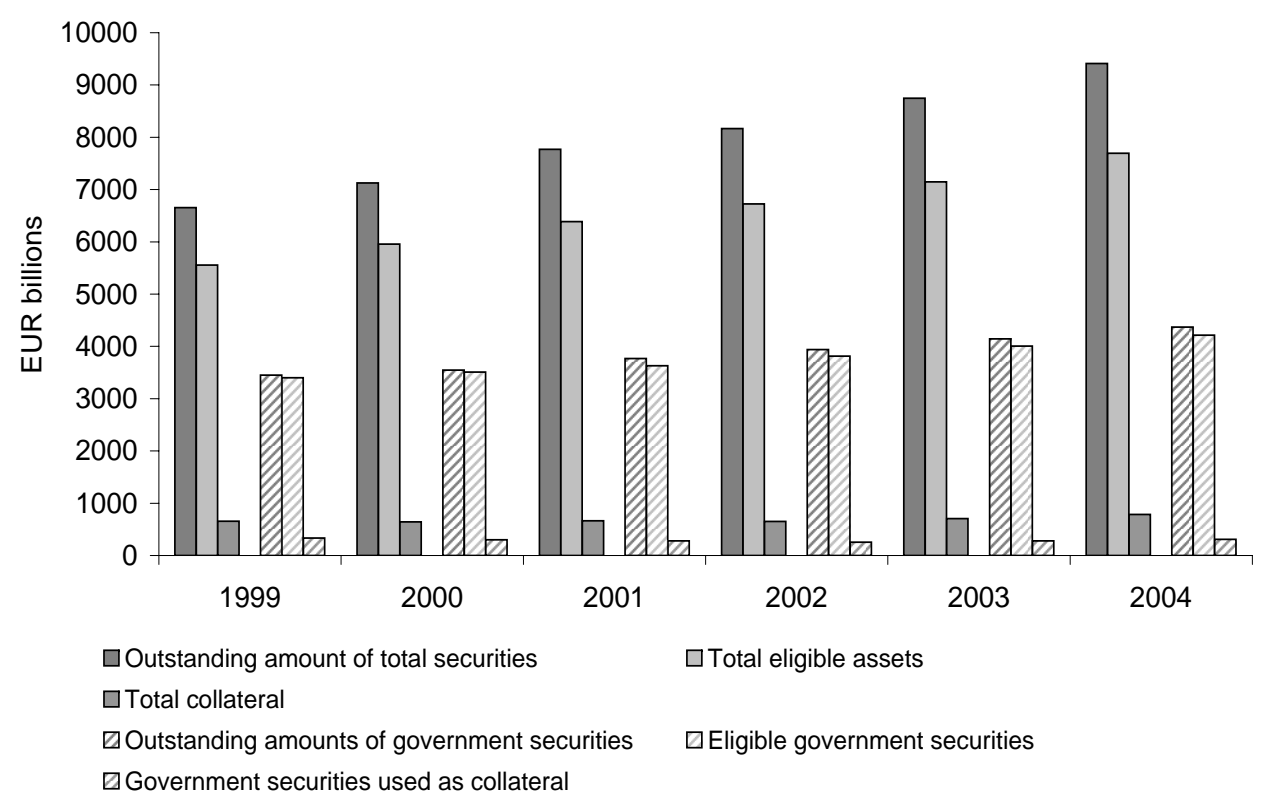

Figure 3: Collateral statistics (Source: ECB).

As this analysis shows, the importance of government financing via issues of bonds increases. This increases the importance of market discipline in pricing the default risks of governments correctly. To affect the price of a certain government bond, the amount used as collateral should be significant. In contrast to this, the amount eligible as collateral is almost as high as the outstanding amount. Therefore, we would expect an influence on the price of government bond coming from the classification as eligible asset rather than from its actual use in monetary policy transactions. 


\section{Government Securities in Monetary Policy Trans- actions and Risk Assessment in Financial Markets}

To investigate the influence of institutional settings surrounding the operation of monetary policy on the pricing of securities, we take a closer look at the relevant procedures (European Central Bank 2005). The ECB monetary policy is implemented through a number of instruments, classified as open market operations, standing facilities and minimum reserves. Liquidity is provided by main refinancing operations, longer-term refinancing operations, fine-tuning and structural operations, as well as operations regarding the marginal lending facility. However, the ECB signals the monetary policy stance only with the main refinancing operations (MRO).

The MRO are conducted as reverse transactions (repurchase agreements or collateralised loans), where banks have to provide collateral to get liquidity. Longer-term refinancing operations also need collateral but are of minor importance. Reverse transactions can also be used in fine-tuning and structural operations. Standing facilities are overnight repurchase agreements or overnight collateralised loans and, therefore, also reverse transaction but with a much shorter time horizon. In addition to the use as collateral, these securities can also be used as assets in outright purchases in the case of fine-tuning and structural operations which play only a minor role. The transactions are executed in accordance with market conventions for the debt instrument used in the transaction. The price is calculated in accordance with the most widely accepted market conventions for the debt instruments used in the transaction (European Central Bank 2005, p. 19).

As this short summary shows, the operating of European monetary policy relies heavily on collateral. All liquidity providing operations are based on adequate collateral. The value of the underlying asset is determined on the basis of a reference price, which is the most representative price in the market. If more than one price is quoted in the market, the lowest price is used. If a tender takes place, the participants are expected to always be in the position to cover the amounts allotted to them by a sufficient amount of underlying eligible assets. If not, a penalty can be imposed by the national central bank, as stated in the respective contractual or regulatory arrangements (European Central Bank 2005).

The assets are used as collateral by transfer of ownership or in form of a pledge granted over relevant assets. Eligible assets have to fulfill certain criteria stated by the ECB to 
protect the Eurosystem from incurring losses in its monetary policy operations ${ }^{3}$, ensuring the equal treatment of counterparties and enhancing operational efficiency (European Central Bank 2005, p. 39).

To keep the market and liquidity risk as low as possible, assets can only be used as collateral if they are evaluated as highly liquid and display low risks. The high liquidity means that buying these securities in the market does not change the price significantly. Only events that change the fundamental value of the asset should influence its price significantly and persistently. This should put a private bank in the position to obtain collateral without 'paying too much'. Illiquid assets are not suitable as collateral: imagine that banks would demand a high amount of securities and as a consequence the price increases considerably. On the one hand, this means that a bank would pay a higher price. On the other hand, this would influence the value of the assets already designated as collateral, because the ECB values the security by its market price. With increasing demand, the price and therefore the valuation of the asset increases, leading to a situation where the central bank demands less assets for a given amount of central bank money. However, because the price is only temporarily higher, the central bank would soon demand additional assets to cover for the then again lower value. The opposite result would occur for falling demand. In any case, the adjustment of the collateral portfolio would generate transaction costs.

The ECB only declares securities as eligible if there are sufficiently liquid markets. ${ }^{4}$ Sufficient liquidity would also prevent the issuer from demanding a collateral premium. Such a premium could arise with a high demand of narrow collateral, leading the issuer to lowering the rate of return (Leinonen 1998, p. 32). Banks are afraid that changes in the supervision in Europe will increase the demand for collateral and therefore lead to the scarcity of cheap collateral (European Central Bank 2004b). Only if eligible assets are available without strong impact on prices, competition between banks is not influenced by the matter of collateral. Then, the problem for a bank is not the availability but the selection of certain securities as collateral from the set of eligible assets. This will not least depend on the opportunity costs of different kinds of collateral.

In case of default of a bank, liquid markets make sure that collateral can be liquidated without much impact on the price of the asset. High liquidity also prevents prices from be-

\footnotetext{
${ }^{3}$ According to the wholesale market, the ECB substitutes counterparty risk with risks resulting from the market price, liquidity, operational and legal risks (Bank for International Settlement 2001, p. 19).

${ }^{4}$ Besides, there are eligible assets on tier 2 which are non-marketable.
} 
ing too volatile. If the market price fluctuates widely, this would imply that the collateral provider had to adapt the amount of assets constantly leading to increasing transaction costs. Securities with low liquidity are therefore prone to a price risk. As a rule, government bonds are described as more liquid than corporate bonds. Because of the low value of the volume of monetary policy repo auctions compared to outstanding amounts of securities, it is to expect that the influence of demand on the market should be low. The amount of collateral needed in central bank tenders depends on the implementation of the monetary policy auctions. First, it is important whether banks have to back up the bidding amount or the allotted amount of central bank money with collateral. For the ECB, only the allotted amount has to be covered by collateral. A second influence from the implementation of monetary policy on collateral issues arises from the possible overlapping of auction periods. The change of the ECB from a two week to a one week repo auction also relaxed the demand for collateral. With a two week auction and an overlap of one week, the assets used as collateral in the first auction could not be used in the second auction. The bidding behaviour of banks in two week auctions can indicate if the bidders are constrained by the collateral request. Nyborg et al. (2002, p. 24) find that there are patterns in the bidding behaviour of banks, hinting to constraints in the bidding behaviour of banks because of collateral needs.

Risk control measures are employed on eligible assets. The total amount of eligible assets is restricted because debt instruments due for repayment before the maturity date of the monetary policy operation, for which they are being designated as underlying assets, cannot be used. Furthermore, no income flow should occur in the period up to the maturity date of the monetary policy operation. Besides the valuation haircut due to the liquidity of the asset, other measures might be introduced by the ECB but are currently not in effect. These are limits in relation to issuers/debtors or guarantors, additional guarantees or the exclusion of certain assets from the list of eligible assets.

The use of government securities as collateral has decreased since 1999, although the amount eligible has increased (European Central Bank 2004a). Even if no government securities have explicitly been prevented from being used as collateral, the ECB publishes an explicit list of securities eligible in monetary policy operations of the central bank. This opens the opportunity to exclude securities if necessary. But for now, this does not seem to have happened. The ECB has also not yet used the possibility to impose quantity restriction for certain assets. Moreover, all government securities are classified in the same evaluation category despite large differences in government debt and deficit. In contrast 
to this practice, Claude Trichet, President of the ECB, announced in an interview that government securities are eligible if rated at least A- from one of the three major rating agencies, Standard \& Poors, Moody's, and Fitch (Buttonwood 2005). The private rating can be seen as a necessary but not sufficient condition for the inclusion of a security in the list of eligible assets. The acceptance of all government securities at the same terms is not followed by the markets to the same extent (see Table 3).

The view that government securities are not risky in Europe, compared to corporate bonds, is by and large matched by the evaluation of different rating agencies. We take a look at the rating history provided by Fitch and S\&P (see Table 3). Both institutions evaluate the members of the EMU as very secure. Nevertheless, both agencies have done some up- and downgrading of EMU countries since 1995. This does not directly contradict the assessment of the ECB. However, the ECB does not discriminate between countries with regard to the eligibility of government securities because the bonds are at least $\mathrm{A}$ rated (Buttonwood 2005). But the market assessment, which is encoded in the rating, may influence the evaluation of the central bank, accepting government securities as collateral. The eligibility of securities may in turn reinforce the assessment of financial markets that these assets have a low risk. We will discuss this possibility in the model contained in the next section. For now, no government security is rated below A-. This implies that all securities have the potential to be included into the list of eligible assets. Nevertheless, the ECB publishes an explicit list. This indicates that the ECB does not exclusively rely on the evaluation by the rating agencies, but also employs own measures to assess risk and liquidity of government bonds. Moreover, as seen in Figure 3, the outstanding amount of government bonds is not entirely matched by the amount of eligible assets. 


\begin{tabular}{|c|c|c|c|c|c|c|c|c|c|}
\hline & \multicolumn{2}{|c|}{ Fitch } & \multicolumn{2}{|r|}{ S\&P } & & \multicolumn{2}{|c|}{ Fitch } & \multicolumn{2}{|c|}{$\mathrm{S} \& \mathrm{P}$} \\
\hline country & rating & date & rating & date & country & rating & date & rating & date \\
\hline \multirow[t]{2}{*}{ Austria } & $\mathrm{AAA}$ & since 1995 & AAA & since 1975 & Ireland & $\mathrm{AAA}$ & Oct 1995 & $\mathrm{AAA}$ & since 1993 \\
\hline & & & & & & $\mathrm{AA}+$ & July 1998 & $\mathrm{AA}+$ & May 1998 \\
\hline \multirow[t]{5}{*}{ Belgium } & $\mathrm{AAA}$ & Oct 1995 & $\mathrm{AAA}$ & since 1992 & & $\mathrm{AAA}$ & Dec 1998 & $\mathrm{AAA}$ & Oct 2001 \\
\hline & $\mathrm{AA}+$ & July 1998 & $\mathrm{AA}+$ & May 1998 & & & & & \\
\hline & AA- & Dec 1998 & & & Italy & AAA & Oct 1995 & AAA & since 1995 \\
\hline & $\mathrm{AA}$ & June 2002 & & & & AA- & July 1998 & $\mathrm{AA}$ & May 1998 \\
\hline & & & & & & $\mathrm{AA}$ & June 2002 & AA- & July 2004 \\
\hline \multirow[t]{2}{*}{ France } & $\mathrm{AAA}$ & since 1995 & $\mathrm{AAA}$ & since 1992 & & & & & \\
\hline & & & & & Luxem- & AAA & since 1995 & AAA & since 1994 \\
\hline \multirow[t]{5}{*}{ Finland } & $\mathrm{AAA}$ & Oct 1995 & $\mathrm{AAA}$ & since 1992 & bourg & & & & \\
\hline & $\mathrm{AA}+$ & July 1998 & $\mathrm{AA}$ & May 1998 & Nether- & AAA & since 1995 & $\mathrm{AAA}$ & since 1992 \\
\hline & $\mathrm{AAA}$ & Aug 1998 & $\mathrm{AA}+$ & Sept 1999 & lands & & & & \\
\hline & & & $\mathrm{AAA}$ & Feb 2002 & Portugal & AAA & Oct 1995 & AAA & since 1993 \\
\hline & & & & & & $\mathrm{AA}$ & July 1998 & AA- & May 1998 \\
\hline \multirow[t]{2}{*}{ Germany } & $\mathrm{AAA}$ & since 1995 & $\mathrm{AAA}$ & since 1992 & & & & $\mathrm{AA}$ & Dec 1998 \\
\hline & & & & & & & & AA- & July 2005 \\
\hline \multirow[t]{5}{*}{ Greece } & A- & Oct 1999 & A- & since 1997 & & & & & \\
\hline & $\mathrm{A}$ & June 2001 & $\mathrm{~A}$ & March 2001 & Spain & AAA & Oct 1995 & $\mathrm{AAA}$ & since 1992 \\
\hline & $\mathrm{A}+$ & Oct 2003 & $\mathrm{~A}+$ & June 2003 & & $\mathrm{AA}$ & July 1998 & $\mathrm{AA}$ & May 1998 \\
\hline & $\mathrm{A}$ & Dec 2004 & $\mathrm{~A}$ & Nov 2004 & & $\mathrm{AA}+$ & Sept 1999 & $\mathrm{AA}+$ & March 1999 \\
\hline & & & & & & AAA & Dec 2003 & $\mathrm{AAA}$ & Dec 2004 \\
\hline
\end{tabular}

Table 3: Rating histories, Local currency rating long-term (Source: S\&P, Fitch).

To further investigate the relationship between monetary policy and financial markets, we look at the basic relationship between the pricing of a government security and the institutional features of monetary policy instruments more closely. The basic links are outlined in Figure 4. The government issues securities to financial markets. A direct financing of government debt by the central banks of the System of European Central Banks is no longer allowed. However, because banks have to back up their borrowing from the central bank with collateral, there is a link between governments and the ECB via the financial markets. It could be that the pricing of government securities does not only rely on information provided by the rating agencies but also on the information provided by the central bank via the acceptance as collateral in monetary policy transactions. The institutional features of the monetary policy operations would therefore influence financial markets. On the one hand, the value of assets used as collateral is determined in the market. On the other hand, the interest rate signalling the policy stance is determined 
in the monetary policy operations, where the asset is used as collateral. One would expect that credit costs depend on the collateral provided. In case of monetary policy operations, this is not the case. This could in turn influence the valuation of eligible assets by financial markets.

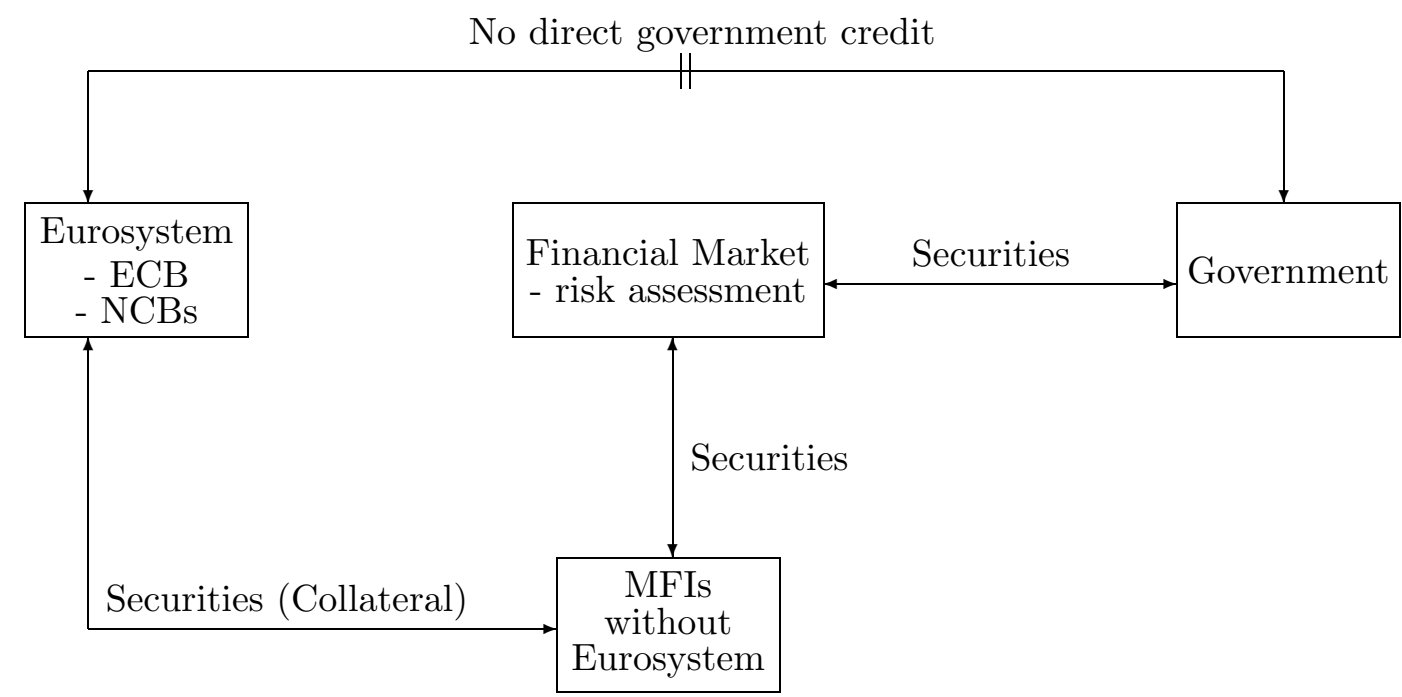

Figure 4: Relationship between monetary policy operations and financial markets with regard to government securities.

\section{Influence of Eligibility as Collateral on the Pricing of Government Securities}

\subsection{Assumption Regarding a Potential Influence}

There are two ways to expect an influence from the classification of a security as eligible for collateral purposes on the pricing of that security and especially on its risk premium. The first influence would occur because of the actual use of the security as collateral. The asset is given to the central bank in exchange for central bank money. For this credit, the private bank pays an interest rate determined by the central bank. This could influence the interest rate paid for obtaining liquidity by issuing the security in the first place. For this channel to work, the collateral should be specific. For specific collateral, only clearly defined securities can be used in the transaction. In this case, there would be a direct link between the liquidity obtained in central bank transactions and liquidity obtained in the market, and an influence on securities prices can be expected (Bank 
for International Settlement 1999). The demand for specific collateral may affect the availability of selected securities and increase the price even for highly liquid securities. But because the Eurosystem accepts general collateral, where the kind of security is not specified, this direct relationship is not given (Bank for International Settlement 1999, p. 12). In addition to that, a change in supply and demand should not influence the price to a large and long-lasting extent, because the ECB only accepts liquid assets as collateral. Then, only the classification as an eligible asset could have an impact and the scarcity of the assets used as collateral (Bank for International Settlement 2001, p. 2).

Therefore, we concentrate on the second influence, the effect the classification as eligible asset has on the pricing of government securities. The eligibility provides a signal with regard to the riskiness of the asset. The signal depends on the potential rather than actual use as collateral. The assessment gives a signal to financial markets with regard to sovereign risk. The classification as potential collateral makes it easier for investors to assign the risk and would be comparable to the rating of private rating agencies. The ECB classifies a security as eligible depending on its own and external assessments. For external assessment, the rating of private rating agencies are referred to (European Central Bank 2004c, p. 74). That is, the evaluation of the central bank depends partly on the assessment of the market. However, markets are not always able to evaluate sovereign risk correctly as the literature regarding market discipline shows. In contrast to a rating agency, the central bank does not publish an explicit rating but makes its opinion generally known through the list of eligible assets. One could translate this into a rating with only two classes, in and out.

The default risk of the government is essential for the determination of the risk premium of government bonds. Sovereign risk for EMU countries would arise because governments are not able to print money or to adjust the exchange rate anymore and national government bond markets are prone to solvency crises as well as to liquidity crises (Lemmen and Goodhart 1999). Potential factors influencing the default risk are the tax raising capability, the ability to control spending, the debt management policies, the degree of federal support, the capacity of the government system to produce coherent governments, and the socioeconomic environment (Lemmen and Goodhart 1999). Moreover, the possibility to diversify default risk in the EU seems to be bound (Arnold and Lemmen 2001). Even if government securities are assumed to be secure compared to corporate bonds, the defaults risk still exists. Moreover, the ECB's requirements for eligible collateral in repo auctions 
are less restrictive than in the interbank repo market (Linzert, Nautz, and Bindseil 2004, p. 32).

Ratings are an important factor that determines yield spreads and influences the pricing of securities at least for corporate bonds (e.g. Gabbi and Sironi 2005 and Elton et al. 2004), since they provide new information to stock markets (Hooper, Hume, and Kim 2005). The rating agencies try to assess the risk by employing an encompassing catalogue of measures. Nevertheless, ratings do not prevent financial markets from underestimating the risks of bonds. If there is a crisis, it may be intensified by a downgrade of the ratings (see the short overview of the literature in Gande and Parsley 2005). The influence of ratings is mostly found for developing countries, whereas bond yields of developed countries do not seem to react to changes in the ratings. This view is supported by the matching of spreads and ratings (see Figure 5). The figure shows the spread as the difference between the country-specific bond yield and the German bond yield. The shaded areas denote times of unchanged ratings. There are two ratings pictured, that of Fitch and that of $\mathrm{S} \& \mathrm{P}$, and the time periods of constant ratings can overlap. For all countries there seem to be no jumps in bond yields following rating changes. This could be because ratings only picture knowledge that is already in the market and incorporated in the prices of the assets.

The assessment of a security as eligible in monetary policy transactions provides another kind of rating besides that of private agencies. But it has to be considered that both ratings, that of agencies and that of the central bank, are not independent of one another, because the central bank relies partly on the rating of agencies. Therefore, it seems plausible to assume that the potential use of collateral influences the risk premium of a government bond in a similar manner as the rating of private agencies. Both should influence the ability of the market to exercise market discipline by influencing the prices of securities. Besides, spillover effects have to be taken into account. Sovereign rating changes do not only affect security prices of the rated country but also those of other countries (Gande and Parsley 2005). If the classification as eligible assets provides information similar to ratings, a "downgrading" by the central bank may not only influence the risk premium of the respective country but also that of other member states of the euro area because of spillover effects. 


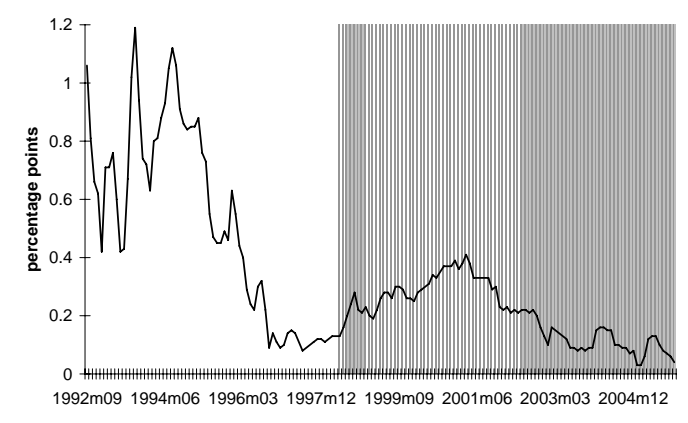

Belgium

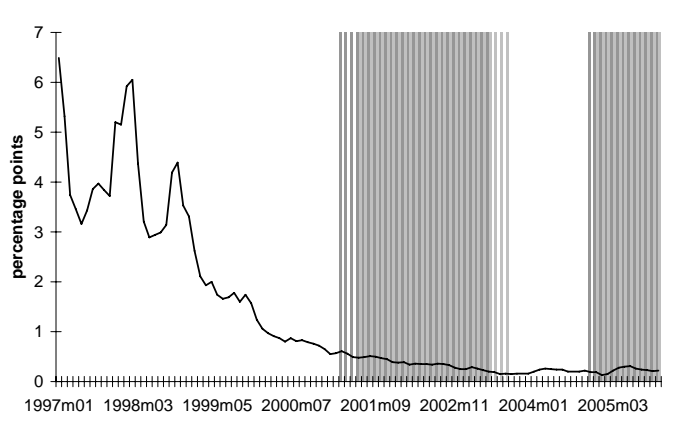

Greece

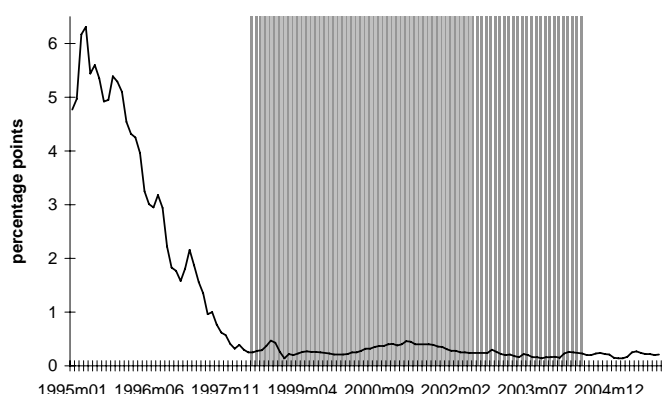

Italy

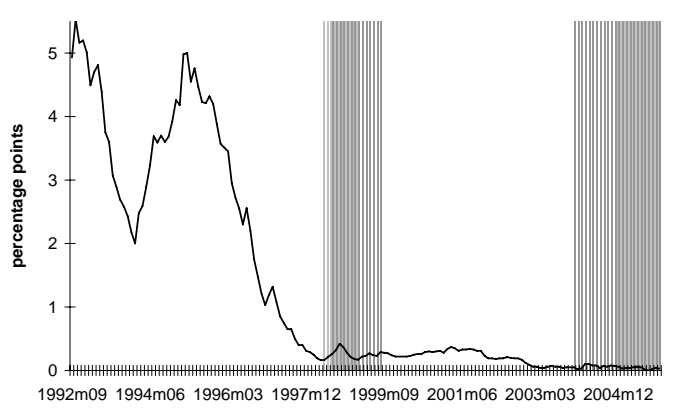

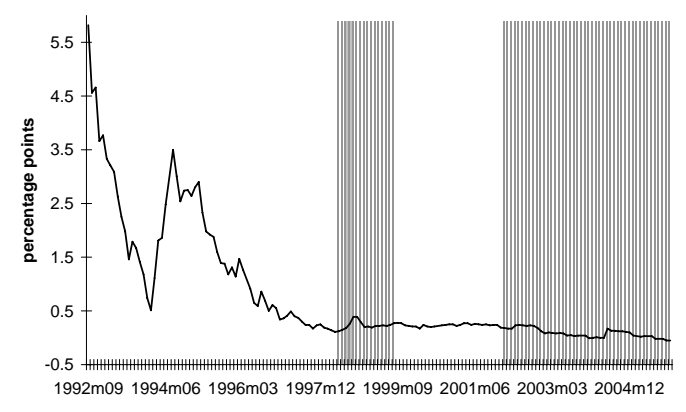

Finland

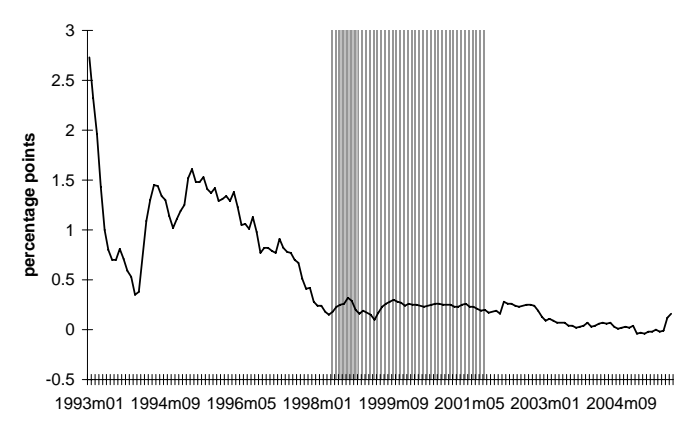

Ireland

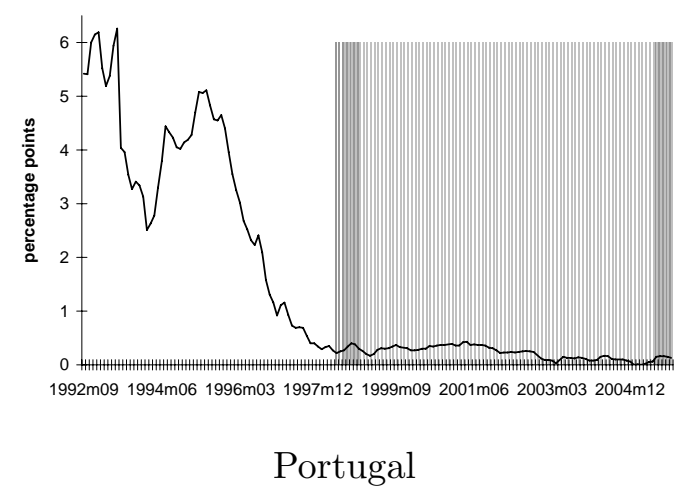

\section{Spain}

Figure 5: Yield spread and rating changes (Source: Eurostat, S\&P and Fitch). 


\section{$5.2 \quad$ A Simple Model on Effects of Signals}

As mentioned above, the rating of private rating agencies and the approval of securities as collateral by the central bank can be interpreted as two different but correlated signals about the default risk of a government bond. Both signals would influence the risk premium demanded by the market. The relative impact of these signals on the risk premium is ultimately an empirical question. However, the ECB has not yet excluded government bonds from the list of eligible assets or assigned government bonds to higher margins. Therefore, there is no empirical investigation possible and we have to rely on theoretical reflections to get an idea about the influence of both signals on the risk premium.

The timing of events is as follows (see Figure 6):

\begin{tabular}{|c|c|c|c|c|}
\hline $\begin{array}{l}\text { Determination } \\
\text { of true risk } \\
\text { premium }\end{array}$ & $\begin{array}{l}\text { Distribution } \\
\text { of risk } \\
\text { premium is } \\
\text { common } \\
\text { knowledge }\end{array}$ & $\begin{array}{l}\text { Agency and } \\
\text { central bank: } \\
\text { Estimation } \\
\text { of true } \\
\text { risk premium }\end{array}$ & $\begin{array}{l}\text { Publication of } \\
\text { agency and } \\
\text { central bank } \\
\text { signal about } \\
\text { true risk } \\
\text { premium }\end{array}$ & $\begin{array}{l}\text { Expectation } \\
\text { formation by } \\
\text { investors about } \\
\text { risk premium }\end{array}$ \\
\hline
\end{tabular}

Figure 6: The timing of events.

The true value of the risk premium is determined. This is done by realising the value of the factors influencing the risk premium such as political and economic circumstances. The investors do not know all influencing factors in detail but have an idea about the range in which the risk premium will be realised. This knowledge can be pictured by a distribution of the risk premium that is common knowledge in the market. The rating agency and the central bank examine the determinants of the risk premium in detail and come to an assessment with regard to the default probability of the government bond. The default probability is published as the rating and provides a signal with regard to the default risk. The ECB equivalent to the rating is the inclusion of the bond into the list of eligible assets. Conditional on the rating, the investors form their expectation with regard to the risk premium. 
Every time a significant change of the factors influencing the risk premium of a government bond appears, the rating agency, the central bank, and the investors should reevaluate the risk premium of the bond. In this case, the sequence of moves described above is realised. Because the underlying factors are supposed to change infrequently, the rating by the agencies and the central bank also changes infrequently as a response to such events. Therefore, we analyse one sequence of events and not a multi-period set up. We regard only a one-time change of the rating that provides a signal about the risk premium. This is equivalent to the assessment of a newly issued government bond rated for the first time. Therefore, the model has no time dimension. The structure is given by the sequence of moves by the nature, the rating agency, and the central bank, and the investors. The sequence of moves also provides the information structure of the model.

To model the influence of the signals theoretically, we make some assumptions with regard to the information content of the signals and the possible information advantage of the rating agencies and the central bank compared to the market. Because of the information differentials with regard to the risk premium, we assume that there exists a 'true' risk premium, $r$, but the market does not know it. However, the distribution of the risk premium with $E[r]=r_{0}$ and $\operatorname{var}(r)=\sigma_{r}^{2}$ is common knowledge in the market. To assess the price for a government bond, an investor will form the expected value of the risk premium using all available signals about the risk of the government bond.

There are two signals available, providing information with regard to the risk of a government bond, namely that of the central bank, $s^{c}$, and that of the rating agency, $s^{a}$. The rating corresponds to the default risk. The rating gives a direct signal with regard to the risk premium. In case of perfect competition and risk neutral banks, the spread between the country-specific yield and the world interest rate, $r$, can be written as (Edwards 1984)

$$
r=\frac{p}{1-p}\left(1+R^{*}\right)
$$

with $p$ the default risk and $R^{*}$ the world interest rate. The risk premium, which is the difference between the idiosyncratic interest rate and the world interest rate, is only determined by the default risk. If the central bank or the rating agency provides its assessment of sovereign risk, it gives a signal with regard to the default risk, $p$. This signal aggregates all country characteristics influencing the spread. The assessment of the default risk then directly determines the risk premium, $r$. In accordance with these assumptions, the empirical literature shows that ratings influence the risk premium. 
If the rating agency or the central bank would correctly predict the default risk, $p$, the rating would reveal the true risk premium, $s=r$, conditional on the assumption that $R^{*}$ is common knowledge in the market. We assume that the rating agency is better informed about government default risk than investors in financial markets. Nevertheless, the signal of the agencies does not reveal the true default risk, because even the agency is not perfectly informed about the risk. The same is true for the central bank. Therefore, we assume that the signal about the true risk premium is disturbed by noise.

To implement these assumptions, we define the signal of the agency as

$$
s^{a}=r+a
$$

with $E\left[s^{a}\right]=r, \operatorname{var}\left(s^{a}\right)=\operatorname{var}(r)+\operatorname{var}(a), \operatorname{var}(a)=\sigma_{a}^{2}$ and $\operatorname{cov}(r, a)=0$.

The noise in the signal of the agency does not depend on the value of the risk premium. On average, the agency is right about the risk premium. The same assumptions are made for the signal of the central bank:

$$
s^{c}=r+c
$$

with $E\left[s^{c}\right]=r, \operatorname{var}\left(s^{c}\right)=\sigma_{r}^{2}+\operatorname{var}(c), \operatorname{var}(c)=\sigma_{c}^{2}$, and $\operatorname{cov}(r, c)=0$.

Both signals are correlated because they are unbiased with respect to the true value of the risk premium. This assumption is given by

$$
\operatorname{cov}\left(s^{a}, s^{c}\right)=\sigma_{r}^{2}+\operatorname{cov}(a, c) \text { with } \operatorname{cov}(a, c) \geq 0 .
$$

Because the agency and the central bank analyse the default risk of the government in question thoroughly, the signals provide information to the investors, $\sigma_{a}^{2}<\sigma_{r}^{2}$ and $\sigma_{c}^{2}<\sigma_{r}^{2}$. The investor will form expectations of the risk premium and takes the signals into account via Bayesian updating. The conditional expected value of the risk premium is given by (Graybill 1961, p. 62ff.)

$E\left[r \mid s^{a}, s^{c}\right]=E[r]+\left[\operatorname{cov}\left(s^{a}, r\right) \quad \operatorname{cov}\left(s^{c}, r\right)\right]\left[\begin{array}{cc}\operatorname{var}\left(s^{a}\right) & \operatorname{cov}\left(s^{a}, s^{c}\right) \\ \operatorname{cov}\left(s^{a}, s^{c}\right) & \operatorname{var}\left(s^{c}\right)\end{array}\right]^{-1}\left(\left[\begin{array}{l}s^{a} \\ s^{c}\end{array}\right]-\left[\begin{array}{l}E\left[s^{a}\right] \\ E\left[s^{c}\right]\end{array}\right]\right)$.

The expected value of the risk premium will be updated according to the value of the signals. The weight that the two signals receive in this process depends on the variances 
and covariances of the different random variables. This results in an expected value of the risk premium, conditional on the two signals:

$$
\begin{aligned}
E\left[r \mid s^{a}, s^{c}\right]=r_{0} & +\frac{\sigma_{r}^{2}\left[\sigma_{c}^{2}-\operatorname{cov}(a, c)\right]}{\sigma_{r}^{2}\left[\sigma_{a}^{2}+\sigma_{c}^{2}-2 \operatorname{cov}(a, c)\right]+\sigma_{a}^{2} \sigma_{c}^{2}-\operatorname{cov}(a, c)^{2}}\left(s^{a}-r_{0}\right) \\
& +\frac{\sigma_{r}^{2}\left[\sigma_{a}^{2}-\operatorname{cov}(a, c)\right]}{\sigma_{r}^{2}\left[\sigma_{a}^{2}+\sigma_{c}^{2}-2 \operatorname{cov}(a, c)\right]+\sigma_{a}^{2} \sigma_{c}^{2}-\operatorname{cov}(a, c)^{2}}\left(s^{c}-r_{0}\right) .
\end{aligned}
$$

If the variance of one signal is higher than that of the other, e.g. $\sigma_{c}^{2}>\sigma_{a}^{2}$, the information contained in the signal of the central bank is more imprecise. In this case, the investor gives the signal of the agency a higher weight. The expected value of the risk premium hence is closer to the signal of the agency.

If the errors in the signals are independent, $\operatorname{cov}(a, c)=0$, the expected value of the risk premium is given by

$$
E\left[r \mid s^{a}, s^{c}\right]=r_{0}+\frac{\sigma_{r}^{2} \sigma_{c}^{2}}{\sigma_{r}^{2}\left[\sigma_{a}^{2}+\sigma_{c}^{2}\right]+\sigma_{a}^{2} \sigma_{c}^{2}}\left(s^{a}-r_{0}\right)+\frac{\sigma_{r}^{2} \sigma_{a}^{2}}{\sigma_{r}^{2}\left[\sigma_{a}^{2}+\sigma_{c}^{2}\right]+\sigma_{a}^{2} \sigma_{c}^{2}}\left(s^{c}-r_{0}\right) .
$$

With dependent errors in the signals, the investor tries to extract the part of the information that is involved in both signals. ${ }^{5}$ In this case, the expected value is not dependent on the variance of the signals but on the variance minus the covariance of the errors. The overlapping information in both signals could be interpreted as exceptionally reliable and should receive special attention in forming the expected value. Because the signals are unbiased, only the part of the signal involved in both signals can give information regarding the true value of the risk premium. In the case of independent signals, this extraction problem does not appear. Nevertheless, the investor has to determine the signal on which he relies more in updating its expectations. Because both signals are unbiased, this would be the signal with the lower variance. To continue the example of a more precise signal of the agency, we again have $\sigma_{c}^{2}>\sigma_{a}^{2}$. Under these circumstances, the signal of the agency receives a higher weight in forming the expectations. But compared to the case of interdependent errors in the signals, the development of the weights of the signals is ambiguous. If the variance of the central bank signal is sufficiently high,

$$
\begin{aligned}
\sigma_{c}^{2} & >\frac{\sigma_{r}^{2}+\sigma_{c}^{2}}{\sigma_{r}^{2}+\operatorname{cov}(a, c)} \sigma_{a}^{2}, \\
\sigma_{c}^{2} & >\frac{\sigma_{r}^{2}+\operatorname{cov}(c, a)}{\sigma_{r}^{2}+\sigma_{a}^{2}} \sigma_{a}^{2},
\end{aligned}
$$

\footnotetext{
${ }^{5}$ The case of completely independent signals is not a reasonable scenario. If the signals are treated as independent they could not be unbiased, the expected value of the signal would be different from the expected value of the risk premium at least for one signal. This would contradict our assumptions.
} 
this would lead to a higher weight of the central bank signal in case of independent errors compared to the situation of correlated errors. Because of the independence of the errors, the information content of the central bank signal could not be judged against the agency signal. Therefore, the central bank signal is treated as an independent source of information leading to the respective higher weight of the signal in the expectations formation process. If the agency signal is sufficiently imprecise, the agency signal would get a higher weight in case of independent signals.

Imagine a situation where the central bank relies on the signal of the agency but adds some valuation of the default risk of its own. The information content of the signals can then be captured by the following set of assumptions

$$
\begin{aligned}
& s^{a}=r+a, \quad s^{c}=r+a+\epsilon \\
& E\left[s^{a}\right]=r_{0}, \quad E\left[s^{c}\right]=r_{0} \\
& \operatorname{var}\left(s^{a}\right)=\sigma_{r}^{2}+\sigma_{a}^{2}, \quad \operatorname{var}\left(s^{c}\right)=\sigma_{r}^{2}+\sigma_{c}^{2}+\sigma_{\epsilon}^{2}, \quad \operatorname{cov}\left(s^{a}, s^{c}\right)=\sigma_{r}^{2}+\sigma_{a}^{2}
\end{aligned}
$$

This would further distort the signal of the central bank beyond that of the agency. In this case, the investors would only take the signal of the agency into account:

$$
E\left[r \mid s^{a}, s^{c}\right]=r_{0}+\frac{\sigma_{r}^{2}}{\sigma_{r}^{2}+\sigma_{a}^{2}}\left(s^{a}-r_{0}\right)
$$

The signal of the central bank would not provide any additional information beyond that of the agency.

For the institutional feature of the Eurosystem to influence the expectations about the risk premium of government securities, it is crucial that the central bank provides a signal to financial markets that is independent in the error term from the error term of the signal of private rating agencies. Because it seems not possible to know about the relationship of the signals, we have to distinguish two cases. First, if both signals are unbiased, but the central bank bases its signal on the rating agency, as suggested by the statements of Trichet, the market would ignore the signal of the central bank. Second, only if the market perceives the central bank as an independent source of information, the signal of the central bank, the classification of a government bond as collateral, matters with respect to the risk premium. 


\section{Conclusion}

With the expected weakening of the SGP, the restriction of government deficit and debt by financial markets via market discipline could be again the focus of attention. For market discipline to work, no restrictions should hinder the pricing of government bonds by the market. Such restrictions could be due to information asymmetries between markets and government or because of possible bail outs of governments by other members of the European Union. But as the analysis shows, the use of government bonds as collateral could also have an influence on the determination of the risk premium of these assets.

As the model predicts, the risk assessment of the central bank could have an influence on the premium of a bond if the markets perceive the central bank as an independent source of information with regard to the default risk of a bond. If the central bank merely adds some noise to the information provided by private rating agencies, there is no influence expected on the yield spread of a government bond. The acceptance of collateral without taking into account different debt levels of the issuing government could then lead to more uniform risk premia of government bonds. Whether this would happen depends on the perception of the central bank as providing information with regard to default risk. In case that equal risk premia are not fundamentally justified and that the classification is influenced by thoughts on non-discrimination between European governments, market discipline as the differentiation of risk premia of government bonds would be more difficult to put through.

It seems possible that the acceptance of all European government bonds without distinction in ECB monetary policy auctions as collateral could impede market discipline. This would be the case if the assignment of equal risk by the ECB is not justified fundamentally. Moreover, the risk assessment of the central bank should not be influenced by political pressure to treat all government bonds in the same way but the central bank should be able to use the measures of evaluation that the ECB has at its disposal. The latter is guaranteed by the independence of the ECB enshrined in the Treaty. The problem of risk assignment is a matter of transparency. More transparency with regard to the classification of securities into the different collateral classes could help financial markets to assign default risks to government bonds and to regard the ECB as an independent source of information. 


\section{References}

Ardagna, S., F. Caselli, and T. Lane (2004), Fiscal Discipline and the Cost of Public Debt Service: Some Estimates for OECD Countries, NBER Working Paper No. 10788.

Arnold, I., And J. Lemmen (2001), The Vulnerability of Banks to Government Default Risk in the EMU, International Finance 4(1), 101-125.

Artis, M. J., And B. Winkler (1997), The Stability Pact: Safeguarding the Credibility of the European Central Bank, EUI Working Paper RSC No. 54.

Bank for International Settlement (1999), Implications of Repo Markets for Central Banks, Report of a Working Group Established by the Committee on the Global Financial System of the Central Banks of the Group of Ten Countries No. 10.

(2001), Collateral in Wholesale Financial Markets: Recent Trends, Risk Management and Market Dynamics, Report prepared by the Committee on the Global Financial System Working Group on Collateral No. 17.

Beetsma, R. M., And H. Uhlig (1999), An Analysis of the Stability and Growth Pact, Economic Journal 109(458), 546-571.

Bernoth, K., L. Schuhknecht, and J. von Hagen (2004), Sovereign Risk Premia in the European Bond Market, CEPR Discussion Paper No. 4465.

Bofinger, P. (2003), Consequences of the Modification of the Governing Council Rules, Briefing Paper for the Committee for Monetary and Economic Affairs (ECON) of the European Parliament, 17 February 2003.

Boonstra, W. (2005), The Stability and Growth Pact in Need of Reform, Intereconomics 40(1), 4-9.

Buiter, W., G. Corsetti, and N. Roubini (1993), Maastricht's Fiscal Rules, Economic Policy 8(16), 58-100.

Buttonwood (2005), The End of Constructive Ambiguity, Mr Tichet?, The Economist Global Agenda, November, 22, 2005, www.economist.com.

Casella, A. (1999), Tradable Deficit Permits, NBER Working Paper No. 7278. 
Codogno, L., C. Favero, and A. Missale (2003), Yield Spreads on EMU Government Bonds, Economic Policy 18(37), 503-532.

De La Dehesa, G. (2005), Unsound Fiscal Policies and Financial Markets Discipline, Briefing Paper for the Committee for Monetary and Economic Affairs (ECON) of the European Parliament, 23 May 2005.

EDWARDS, S. (1984), LDC Foreign Borrowing and Default Risk: Am Empirical Investigation, 1976-80, American Economic Review 74(4), 726-734.

Eichengreen, B., And J. von Hagen (1996), Fiscal Policy and Monetary Union: Federalism, Fiscal Restrictions, and the No-Bailout Rule, in: Siebert, H. (ed.), Monetary Policy in an Integrated World Economy, Tübingen, 211-231.

Eichengreen, B., And C. Wyplosz (1998), The Stability Pact: More Than a Minor Nuisance?, Economic Policy 13(26), 67-113.

Eijffinger, S. C. (2003), How Can the Stability and Growth Pact be Improved to Achieve both Stronger Discipline and Higher Flexibility, Intereconomics 38(1), 10-15. (2005), Reform of the Stability and Growth Pact: Evaluating the European Commission's Communication of September 2004, Intereconomics 40(1), 10-13.

Elton, E. J., M. J. Gruber, D. Agrawal, and C. Mann (2004), Factors Affecting the Valuation of Corporate Bonds, Journal of Banking and Finance 28(11), 2747-67.

Engen, E., And R. G. Hubbard (2004), Federal Government Debts and Interest Rates, NBER Working Paper No. 1068.

European Central Bank (2004a), Annual Report, Frankfurt a.M.

(2004b), Measures to Improve the Collateral Framework of the Eurosystem: Summary of the Answers to the Public Consultation, 15 January 2004.

- (2004c), Risk Mitigation Methods in Eurosystem Credit Operations, Monthly Bulletin May, 71-79.

(2005), The Implementation of Monetary Policy in the Euro Area, General Documentation on the Eurosystem Monetary Policy Instruments and Procedures, February 2005. 
European Commission (2004), Strengthening Economic Governance and Clarifying the Implementation of the Stability and Growth Pact, COM 581, Brüssel.

Fitoussi, J.-P. (2005), Fiscal Indiscipline: Why no Reaction yet by the Market?, Briefing Paper for the Committee for Monetary and Economic Affairs (ECON) of the European Parliament, 23 May 2005.

Flandreau, Marc, J. L. C., And F. Zumer (1998), Stability Without a Pact? Lessons from the European Gold Standard, 1880-1914, Economic Policy 13(26), 115-49.

Frenkel, J. A., And M. Goldstein (1991), Monetary Policy in an Emerging European Economic and Monetary Union, IMF Staff Papers 38(2), 356-373.

Gabbi, G., And A. Sironi (2005), Which Factors Affect Corporate Bonds Pricing? Empirical Evidence from Eurobonds Primary Market Spreads, European Journal of Finance 11(1), 59-74.

Gande, A., And D. Parsley (2005), News Spillovers in the Sovereign Debt Market, Journal of Financial Economics 75(3), 691-734.

Graybill, F. A. (1961), An Introduction to Linear Statistical Models, vol. I., New York. Hedbávný, P., O. Schneider, and J. Zápal (2005), A Fiscal Rule that Has Teeth: A Suggestion for a 'Fiscal Sustainability Council' Underpinned by the Financial Markets, CESifo Working Paper No. 1499.

Hefeker, C. (2003), Credible At Last? Reforming the Stability Pact, Intereconomics $38(1), 15-18$.

Heinemann, F. (2004), Die Strategische Klugheit in der Dummheit - Keine Flexibilisierung des Stabilitätspakts ohne Entpolitisierung, Zeitschrift für Wirtschaftspolitik $53(1), 62-71$.

Hooper, V. J., T. P. Hume, And S.-J. Kim (2005), Sovereign Rating Changes - Do they Provide New Information for Stock Markets?, http://ssrn.com/abstract=685661.

Lane, T. D. (1993), Market Discipline, IMF Staff Papers 40(1), 53-88.

Leinonen, H. (1998), Interbank Funds Transfer System: Liquidity Needs, Counterparty Risks and Collateral, Bank of Finland Discussion Paper No. 16. 
Lemmen, J. J., and C. A. Goodhart (1999), Credit Risks and European Government Bond Markets: A Panel Data Econometric Analysis, Eastern Economic Journal 25(1), $77-107$.

Linzert, T., D. Nautz, and U. Bindseil (2004), The Longer Term Refinancing Operations of the ECB, ECB Working Paper No. 359.

Nyborg, K. G., U. Bindseil, and I. A. Strebulaev (2002), Bidding and Performance in Repo Auctions: Evidence from ECB Open Market Operations, ECB Working Paper No. 157.

Scotт, H. S. (2004), Market Discipline for Financial Institutions and Sovereigns, in: Borio, C. et al., Market Discipline across Countries and Industries, Cambridge, Mass., $69-77$.

von Hagen, J. (2003), Fiscal Discipline and Growth in Euroland Experiences with the Stability and Growth Pact, ZEI Working Paper B06-2003.

Wyplosz, C. (2005), Fiscal Indiscipline: Why no Reaction yet by the Market?, Briefing Paper for the Committee for Monetary and Economic Affairs (ECON) of the European Parliament, 23 May 2005. 